\title{
Antenatal Education Model Based Gamification in Terms of Knowledge and Attitude Among Pregnant Women in the Antenatal Classes
}

\author{
Erlin Chusnia Putri ${ }^{1}$, Rasipin $^{2}$, Bedjo Santoso $^{3}$ \\ ${ }^{1,2,3}$ Health Polytechnic od Ministry of Health Semarang, Indonesia \\ Tirto Agung Rd, Semarang Jawa Tengah 50268, Indonesia
}

\begin{abstract}
The maternal mortality rate remain high in Indonesia. MMR in Indonesia around $80 \%$ of obstetric problems. Indonesia has developed the antenatal class program to improving knowledge and attitude for pregnant women. Antenatal class is an important component for pregnant women to improve their knowledge and skills during pregnancy, childbirth and the postnatal period. Educational methods using conventional methods are becoming obsolete and innovative educational methods have been developed. The aim of the research is to create antenatal education model based gamification to improve knowledge and attitude of pregnant women.The research we implemented Research and Development (R\&D) method and quasi experimental with a control group pre-test and post-test design. Research subjects pregnant women were given education by ladder snakes and the control group by pregnancy booklets for 10 days meeting. The results show that antenatal education model is worthy of a education media with $p$-value of 0,000 and the application of this education based gamification after 10 days is effective in increasing knowledge $(p=0,001)$ and attitudes $(p=0,001)$ better than control group. According of the resultsAn antenatal education based on gamification is reliebel to improving knowledge and attitudes of pregnant women. An antenatal education based on gamification can be applied to antenatal classes
\end{abstract}

Keywords:- Antenatal education; Gamification; Maternal Knowledge; An Antenatal Classes Education.

\section{INTRODUCTION}

Antenatal care (ANC) is a pregnancy services to monitor the possibility of complications and plan optimal management of high risks and reduce maternal and fetal morbidity and mortality.[1] Maternal mortality is a problem in the world of 295,000 women who died during pregnancy until delivery in 2017. The cause of maternal death $73 \%$ is caused by obstetric problems.[2] Maternal deaths show that they're lack of knowledge about danger signs during pregnancy and being late in making decision and delays in handling the referral site.

An effort was made to decrease maternal rates by antenatal care services and antenatal classes of pregnant women. Based on research Mcmillan (2019) antenatal class can improve the behavior of pregnant women, and reduce the value of antenatal care drop outs.[3] Based on Lucia's research (2015) antenatal classes can increase maternal knowledge of pregnant women 4,54\%.[4]

Based on preliminary studies, Brebes Regency has the highest pregnancy dropout rate in Central Java with a dropout rate of $12.44 \%$, which means that the awareness of pregnant women to check their pregnancy is still low. The implementation of a antenatal classes is considered sufficient to increase knowledge but has no influence on improving the attitude of pregnant women. The antenatal classes is not optimal because of the limited facilities and infrastructure, and lack of support from the community, especially in the family support.[5] So it is necessary to create an innovative education model in antenatal classes using gamafication.

Gamification is game or non-application game design elements with a rules.[6] Gamification design like a game to provide practical solutions by building engagement with groups with rules and rewards. Gamification in this study adopted from the folk game that is a game of snakes and ladders which was modified and given for 10 days. In that game there are a question card to be answered by pregnant women.

Based on the above background, many pregnant women have a low level of awareness of antenatal visits so that knowledge and attitudes about obstetric health are also low. Efforts that have been given by holding antenatal classes are still lacking because of limited educational media. So that more innovative education with gamification model so that education becomes more active, antenatal classes become attractive, efficient and enjoyable and can increase the knowledge and attitudes of pregnant women.

\section{MATERIALS AND METHODS}

The research method used is Research and Development (R\&D). The use of this method consists of 5 steps, namely data collection, design and build a model, expert validation and model test and model results[7]

The research design in this study used a quasi experiment design with pre-test and post-test control group design. This study involved pregnant women consisting of 2 groups, of which one group received antenatal care education 
model and the second group received education using a booklet. In the intervention group pretest before education is given to measure the knowledge and attitudes of pregnant women. Then the mother is asked to come to the class of pregnant women every 3 days for 10 meetings. At the last meeting, the mother returned to work on the post test questions. In the control group, mothers did independent learning using a booklet that would be monitored and reminded every 3 days.

\section{RESULTS}

\section{A. Data collection}

Based on the results of interviews and literature studies, it can be concluded that the provision of antenatal education is important as risk prevention during pregnancy and providing education that is interactive and innovative can improve the knowledge and attitudes of pregnant women.

\section{B. Design and build}

The results of data collection used to create a design model. The results of information gathering need education media on the implementation of classes for pregnant women so as to increase the knowledge and attitudes of pregnant women. So the researchers made an antenatal education model based on gamification as an effort to improve the knowledge and attitudes of pregnant women.

\section{Expert Validation}

\begin{tabular}{|c|c|c|c|}
\hline \multicolumn{4}{|c|}{ Expert Validation } \\
\hline & $\mathbf{n}$ & $\mathbf{f}(\%)$ & p-value \\
\hline Relevant & 10 & 100 & \multirow{2}{*}{0,007} \\
\hline Irrelevant & 0 & 0 & \\
\hline
\end{tabular}

Table 1:-Antenatal Education Statistical Test Validation

From The Expert

*Interclass correlation coefficient

Based on tabel 1 the of expert validation for the feasibility of the model shows the $\mathrm{p}$-value $=0.007$ which means that the antenatal education model is relevant as an educational model for pregnant women as an effort to improve the knowledge and attitudes of pregnant women.

\section{Model test}

\begin{tabular}{|c|c|c|}
\hline \multicolumn{3}{|c|}{ Normality test } \\
\hline \multirow{2}{*}{ Variables } & \multicolumn{2}{|c|}{ p-value } \\
\cline { 2 - 3 } & $\begin{array}{c}\text { Intervention } \\
(\mathbf{n = 2 2})\end{array}$ & $\begin{array}{c}\text { Control } \\
(\mathbf{n}=\mathbf{2 2})\end{array}$ \\
\hline Knowledge (pre-test) & 0,014 & 0,000 \\
\hline Knowlegde (post-test) & 0,000 & 0,070 \\
\hline Attitude (pre-test) & 0,033 & 0,094 \\
\hline Attitude (post-test) & 0,019 & 0,027 \\
\hline
\end{tabular}

Table 2:- Data Normality Test of Pregnant Women *Shapiro wilk
Based on Tabel 2 data normality tests for the knowledge and attitudes of pregnant women shows that the p-value $<0.05$ so that it can be concluded that the data are normally distributed then using non-parametric tests.

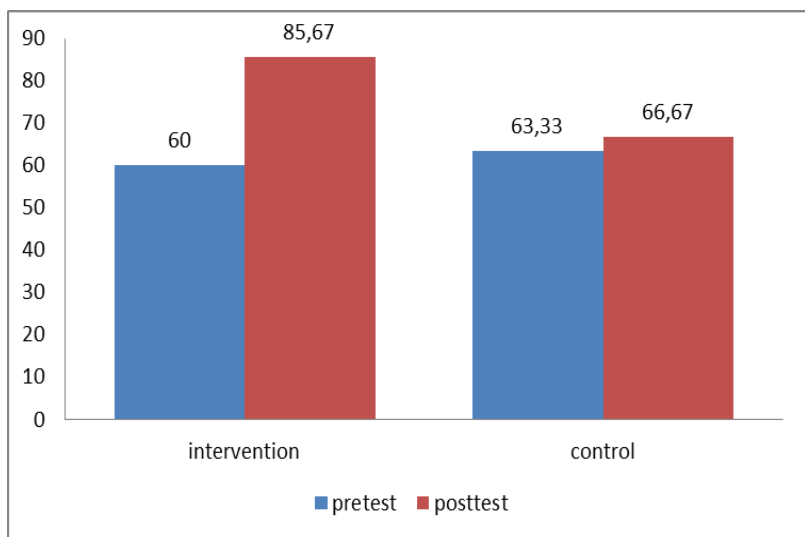

Fig: 1-The Average Value of Knowledge of Pregnant Women Pre-Test and Posttest

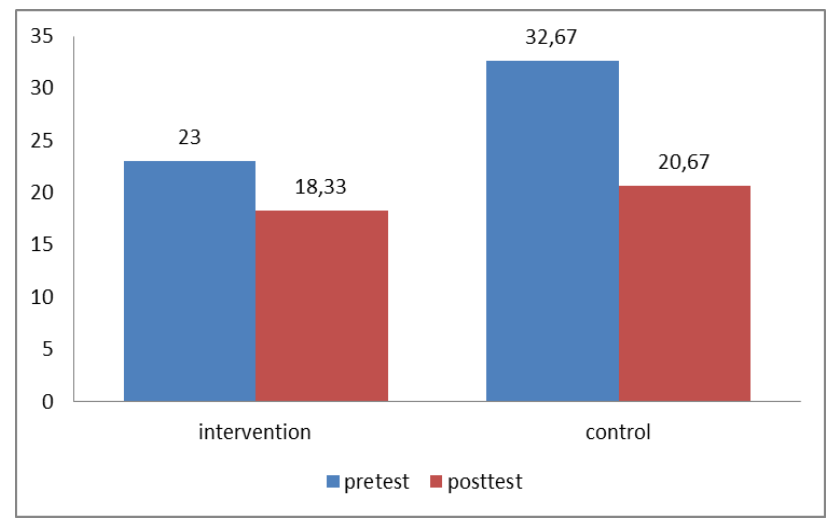

Fig: 2-The Average Value of Attitudes of Pregnant Women Pretest-Posttest

Based on the figure above the average value of knowledge and attitudes of pregnant women has increased. The value of knowledge in the pretest intervention group 43,6 increased to 86,67 , in the pretest control group 63,33 increased to 66,67 . The attitude value in the pretest intervention group 25,36 increased to 30 , in the control group pre test 18,33 increased to 20,67 .

\begin{tabular}{|c|c|c|c|c|c|}
\hline \multicolumn{2}{|c|}{ Group } & \multicolumn{2}{|c|}{ Knowledge } & \multicolumn{2}{c|}{ Attitude } \\
\cline { 3 - 5 } \multicolumn{2}{|c|}{} & $\begin{array}{c}\text { Mean } \pm \\
\text { SD }\end{array}$ & $\begin{array}{c}\text { p- } \\
\text { value }\end{array}$ & $\begin{array}{c}\text { Mean } \pm \\
\text { SD }\end{array}$ & $\begin{array}{c}\text { p- } \\
\text { value }\end{array}$ \\
\hline Intervention & Pre & $43,6 \pm$ & 0,001 & $25,36 \pm$ & 0,001 \\
& & 9,3 & & 2,9 & \\
\cline { 2 - 3 } & Post & $96,3 \pm$ & & $33,9 \pm$ & \\
Control & Pre & $59,5 \pm$ & 0,001 & $23,72 \pm$ & 0,001 \\
& & 9,5 & & 2,2 & \\
\cline { 3 - 3 } & Post & $76,8 \pm$ & & $25,22 \pm$ & \\
& & 11 & & 2,63 & \\
\hline
\end{tabular}

Table 3:- Test Data Pairs Pre and Post Test of Intervention Group and Control Group

* Wilcoxon 
Based on table 3 the results of paired data effectiveness test on the value of knowledge of the intervention group showed that the $\mathrm{p}$-value was $0,001(\mathrm{p}<0,05)$ and the control group was $p$-value 0,001 ( $p<0.05)$. In the value of the attitude of the intervention group showed that the $\mathrm{p}$-value of $0,001(\mathrm{p}<0,05)$ and in the control group $\mathrm{p}$-value of 0,001 ( $\mathrm{p}$ $<0,05)$ means that themodel antenatal education based on gamification and booklets pregnancycan increase the knowledge of pregnant women.

\begin{tabular}{|c|c|c|c|c|c|}
\hline \multirow{2}{*}{\multicolumn{2}{|c|}{ Group }} & \multicolumn{2}{|c|}{ Knowledge } & \multicolumn{2}{|c|}{ Attitude } \\
\hline & & \multirow{3}{*}{$\begin{array}{c}\begin{array}{c}\Delta \text { Mean } \\
\pm \text { SD }\end{array} \\
52.72 \pm \\
9.35\end{array}$} & $\begin{array}{c}\text { p- } \\
\text { value }\end{array}$ & \multirow{3}{*}{$\begin{array}{c}\begin{array}{c}\Delta \text { Mean } \\
\pm \text { SD }\end{array} \\
8.59 \pm \\
3.03\end{array}$} & $\begin{array}{c}\text { p- } \\
\text { value }\end{array}$ \\
\hline \multirow{2}{*}{ Intervention } & Pre-test & & \multirow{4}{*}{0.001} & & \multirow{4}{*}{0.001} \\
\hline & Posttest & & & & \\
\hline \multirow[t]{2}{*}{ Control } & Pretest & \multirow{2}{*}{$\begin{array}{c}17.27 \pm \\
10.31\end{array}$} & & \multirow{2}{*}{$\begin{array}{c}1.04 \pm \\
1.91\end{array}$} & \\
\hline & posttest & & & & \\
\hline
\end{tabular}

Table 4:- Test Data is Unpaired Intervention Group and Control Group

* Mann Whitney

Based on table 4 the results of the test of unpaired data on the value of knowledge between the intervention group and the control group experienced a significant difference significantly proven $p$-value $0,001(p<0.05)$ and the value of the attitude $p$-value $0,001(\mathrm{p}<0.05)$ which means that the gamen-based antenatal education model is effective in increasing the knowledge and attitude of pregnant women.

\section{E. MODEL RESULT}

The snake and ladders based gamification is the output of the development of antenatal education models and health media education for pregnant women. In that game there are a question card to be answered by pregnant women. Game snake and ladders carpet with large size $4 \times 3$ meters in which there are 34 boxes designed. The material used to make snakes and ladders is albatross, this material has a smooth and strong texture. In addition to the snakes and ladders carpet, there are also 4 cards and 4 colors yellow, red, green, and blue. The game is designed as attractive as possible and with bright colors to make it look interesting to play. Snakes and ladders game is played by 5 people in one game, the order of players in this game is determined randomly.

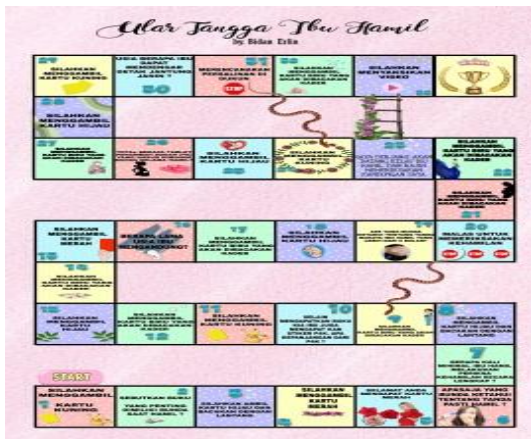

Fig: 3-Antenatal Education Game Based Gamification: A Snakes And Ladders Game for Pregnant Women

\section{DISSCUSION}

Antenatal education model based gamification is relevant as an educational model for pregnant women as an effort to improve the knowledge and attitudes of pregnant women based validation expert. Implementation of antenatal education model applied to pregnant women in the antenatal class can improve the knowledge and attitudes of pregnant women $(p=0,001)$. Based on Balami's research (2019) providing education to pregnant classes which is carried out routinely can increase the knowledge and behavior of pregnant women.[8]

The first phase of the implementation of snakes and ladders is very enthusiastic this is due to new and innovative education. Rothwell's research (2019) with game-based education can result in an increase in knowledge that is far better than education with media leaflets.[9] Snake ladder education for pregnant women in addition to presenting questions also contains educational video screenings, which every day feature different videos so that mothers do not feel bored. Educational media using video display more realistic because there is an element of audio in its delivery and there is an element of vision.[10] The screening of this video can encourage emotional reactions that can trigger memory. This is supported by Pinto's research (2019) by examining respondents' emotional reactions after being givenshows audiovisual viewed throughactivity electrodermal and by pupillometry the results of the study mention audiovisuals are effective in increasing and understanding information so as to increase knowledge.[11] Based on Wallace's research (2019) education with video views can increase the knowledge and value of respondents' confidence because in the video there are clinical demonstrations that are practiced directly.[12] Responden will have illustrations directly from the presentation making it easier for mothers to apply it.

The results score of attitudes of the effectiveness of unpaired test results shows that the value of $p$-value $=0,001$ $(\mathrm{p}<0.05)$, which means that the application of the antenatal education model effective in improving the attitude of pregnant women. This indicates the respondent has reacted in accordance with the information provided, after someone is given information and then consider the information. Attitudes can be formed when someone gets information, reacts and acts.[13] The application of gamification to learning with the rules of the game, ranking and prizes can motivate mothers to spur mothers to participate in learning well and give active reactions or responses.[14]

Providing group education in antenatal classes involving interactions between fellow pregnant women and midwives will foster confidence in pregnant women. Group learning like this will increase the experience of mothers and the knowledge of pregnant women because mothers will exchange experiences and social values between each pregnant woman. Provision of information repeatedly is one way of providing information so that it is more easily conveyed and accepted by respondents. 


\section{CONCLUSIONS}

Antenatal education model development is an innovative new thing to improve the engagement of pregnant women. Antenatal education model is relevant as an educational model in the antenatal classes and implementation antenatal education model more effective to increasing knowledge and attitudes of pregnant women than education with booklet.

\section{REFERENCES}

[1]. L. M. Ran van der Wal, Mary Taleh, "The (in)effectiveness of Antenatal Care in Reducing Maternal Mortality and Promoting Maternal Health in Developing Countries," McGill's Student Glob. Heal. J., vol. 5, no. 1, pp. 56-60, 2016.

[2]. World Health Organization, "Maternal Mortality," 2019. [Online]. Available: https://www.who.int/newsroom/fact-sheets/detail/maternal-mortality. [Accessed: 09-Oct-2019].

[3]. S. Mcmillan, "Maternal and paternal expectations of antenatal education across the transition to parenthood," Br. J. Midwifery, vol. 27, no. 4, pp. 235$241,2019$.

[4]. S. Lucia, A. Purwandari, and E. Pesak, "Pengaruh Pelaksanaan Kelas Ibu Hamil Terhadap Pengetahuan Tentang Persiapan Persalinan," J. Ilm. Bidan, vol. 3, no. 1, pp. 61-65, 2015.

[5]. E. Saragih, H. Purwadi, and I. Isharyanto, "Evaluation on Health Policy Implementation for Decreasing Maternal Mortality Rate through Prenatal Class Program in East Ogan Komering Ulu, South Sumatera," J. Heal. Policy Manag., vol. 4, no. 2, pp. 111-116, 2019.

[6]. L. . N. and D. D. S. Deterding, R. Khaled, "Gamification: toward a de- finition," Proc. CHI 2011 gamification Work. Proc., 2011.

[7]. A. L. D. Buisman and M. C. J. D. Van Eekelen, "Gamification in educational software development," Proc. - CSERC 2014 Comput. Sci. Educ. Res. Conf., pp. 9-20, 2014.

[8]. A. D. Balami, S. M. Said, N. A. M. Zulkefli, N. Bachok, and B. Audu, "Effects of a health educational intervention on malaria knowledge, motivation, and behavioural skills: A randomized controlled trial PACTR201610001823405 PACTR," Malar. J., vol. 18, no. 1, pp. 1-14, 2019.

[9]. E. Rothwell, E. Johnson, B. Wong, N. C. Rose, G. Latendresse, R. Altizer, J. Zagal, M. Smid, A. Watson, and J. R. Botkin, "The Use of a Game-Based Decision Aid to Educate Pregnant Women about Prenatal Screening: A Randomized Controlled Study," Am. J. Perinatol., vol. 36, no. 3, pp. 322-328, 2019.

[10]. M. D. Ismowati, S. Mulidah, and P. Hastuti, "Efektivitas Media AVA dan Leaflet dalam Penyuluhan tentang HIV/AIDS terhadap Peningkatan Pengetahuan Remaja di SMP Negeri 1 Sumpiuh Kabupaten Banyumas Tahun 2011,' J. Kebidanan, vol. 2, no. Oktober 2013, pp. 28-35, 2013.
[11]. R. A. Tubelo, F. F. Portella, M. A. Gelain, M. M. C. de Oliveira, A. E. F. de Oliveira, A. Dahmer, and M. E. B. Pinto, "Serious game is an effective learning method for primary health care education of medical students: a randomized controlled trial," Int. J. Med. Inform., 2019.

[12]. L. M. Wallace, Y. Ma, L. Q. Qiu, and O. M. Dunn, "Educational videos for practitioners attending Baby Friendly Hospital Initiative workshops supporting breastfeeding positioning, attachment and hand expression skills: Effects on knowledge and confidence," Nurse Educ. Pract., vol. 31, no. April, pp. 7-13, 2018.

[13]. A. Siwiendrayanti, E. T. Pawenang, and S. Indarjo, "Changes in Knowledge, Behavior and Environmental Control for Filariasis Prevention with 'MANDIRI' Pocket Book on Society in Pekalongan City: A Longitudinal Study,” J. Pendidik. IPA Indones., vol. 8, no. 2, pp. 177-184, 2019.

[14]. M. A. Scaffidi, R. Khan, C. M. Walsh, M. Pearl, K. Winger, R. Kalaichandran, P. Lin, and S. C. Grover, "Protocol for a randomised trial evaluating the effect of applying gamification to simulation-based endoscopy training," BMJ Open, vol. 9, no. 2, pp. 1-7, 2019. 